\title{
Academic stress in adolescent students of an islamic-based school: The correlation with parenting style and spirituality
}

\author{
Intan Nurul Dwi Utari, ${ }^{1}$ Achir Yani S. Hamid ${ }^{2}$ \\ ${ }^{1}$ Faculty of Nursing, Universitas Indonesia, Depok, West Java; ${ }^{2}$ Department of Mental Health Nursing, Faculty \\ of Nursing, Universitas Indonesia, Depok, West Java, Indonesia
}

\begin{abstract}
Background: Adolescents are vulnerable to experiencing academic stress because of exams and their expectations about their careers. Proper parenting styles from parents can reduce students' academic stress. Also, Islamic-based schools develop youth spirituality so it can reduce academic stress. This study aimed to identify the correlation of parenting styles and spirituality with academic stress in adolescent students of an Islamic-based school.

Design and Methods: The study was used descriptive correlative with a cross-sectional approach. Data was collected online started from April $3^{\text {rd }}$ to May $10^{\text {th }}, 2020$, with 109 respondents of the $12^{\text {th }}$-grade senior student at Islamic-based high school MAN Jakarta Timur. Respondents were selected by simple random sampling. This study used the Parental Care Style Questionnaire, the Spiritual Involvement and Beliefs Scale, and the Educational Stress Scale for Adolescents. Data were analysed using the Pearson correlation analysis (CI 95\%).

Results: There was a significant negative correlation between the democratic parenting style and academic stress level $(p=0.000)$. There was a negative correlation between spirituality level and academic stress level $(\mathrm{p}=0.000)$.

Conclusions: This study suggests the parents use the democratic parenting style by encouraging and giving comfort to their children to be open to their parents about academic problems. Islamic-based schools should carry out routine religious programs, such as reading the Qur'an every day before classes start.
\end{abstract}

\section{Introduction}

Adolescence is a phase for an individual to reach the maturity level both physically and psychologically and acquire an identity. ${ }^{1}$ Nevertheless, they are prone to mental health problems that can reduce their role functions. ${ }^{2}$ The factors that triggered mental health problems in adolescence can be worse due to adolescents' characteristics, particularly in late adolescence. This adolescent age group experiences a phase of changes in various physical, cognitive, psychosocial, psychosexual, and spiritual aspects. Mood instability and the transition phase in adolescents can increase their stressors. Furthermore, schools can also be stressors for students due to the academic demands they receive.

Stressors in life usually trigger stress. Stress is when a person is unable or difficult to adjust to situations, problems, and goals in life. ${ }^{3}$ The classifications of stress are eustress and distress. ${ }^{4}$ Eustress is a type of stress that does not threaten individual wellbeing. This type of stress will motivate someone, such as pleasure and hope.

Conversely, distress is a type of stress that can damage or threaten a person's well-being. This type of stress will cause feelings of anger or fear. Other stress classifications are mild stress, moderate stress, and severe stress..$^{5}$ Mild stress lasts a few moments, a few minutes, or several hours. For example, when someone is stuck in traffic, will face a test, gets scolded, or feels forgotten. Moderate stress can last for hours, days, or even weeks. For example, when there is a disagreement with other people that leads to poor interpersonal relationships, problems in the family, and excessive academic burden. Severe stress lasts even longer, and it can last for weeks, months, even years.

Academic stress is a condition of psychological stress that comes from all academic stressors. ${ }^{6}$ Academic stress includes a person's subjective perception of academic conditions due to school or academic demands. ${ }^{7}$ Factors that can lead to students' academic stress are including learning burden, grades, expectations, hopelessness, and assignments. ${ }^{6}$ Academic stress can also be classified into mild stress, moderate stress, and severe stress based on its severity. The more severe the stress level, it can lead to depression.

The prevalence of depression in adolescents in Indonesia is relatively high due to internal and external factors. The main results of the basic health research by the Ministry of Health of the Republic of Indonesia showed that $6 \%$ of the population at the age of 15 years old and over in DKI Jakarta are depressed. ${ }^{8}$ From 2013

Significance for public health

Education could cause academic stressors for students. Low stress can make students are motivated to study harder. Meanwhile, moderate stress on students can reduce learning performance and can even lead to depression. Therefore, it is necessary to have coping sources that can support students to cope with academic stress. The results of this study indicate that there is a significant negative relationship between academic stress with democratic parenting style and spirituality. The results of this study can be beneficial for public health in order to be able to develop strategies to reduce the prevalence of academic stress in students. The authors suggest giving counselling of parenting styles and student academic stress to parents. Also, the authors suggest giving health education about stress management to students. 
to 2018, the percentage of mental-emotional disorders in adolescents aged 15 years old and over in DKI Jakarta increased by $4.5 \%$ from $5.5 \%$ to $10 \%{ }^{8}$ Positive relationships with families and appropriate parenting style can be a sound support system for adolescents in managing academic stress. ${ }^{9}$ According to Hoskins, the ideal form of parenting is the democratic parenting style. ${ }^{10}$ Besides parenting styles, appropriate coping sources can help adolescent students confront academic stress. Berman et al. stated that spiritual practice and beliefs are the sources of coping for individuals. ${ }^{1}$ Adolescents will usually follow the beliefs that exist in their environment. However, they also begin to think critically and analyse these beliefs objectively, especially in their late adolescence to early adulthood. ${ }^{11}$ Spirituality in adolescents can develop in the school environment because most teens' time is spent in school. A study conducted by Krok regarding spirituality and coping with stress in 221 late adolescents at the age of 16-20 found that spirituality was associated with a task-oriented coping approach to stressors so that students could take actions to generate alternative problem-solving. ${ }^{12}$ Based on Yusuf et al., one factor that can affect an individual's spirituality is socio-cultural factors. ${ }^{11}$ Therefore, an Islamic-based school can influence the spiritual development of adolescent students because it can support students' spirituality by the Islamic-based daily activities such as have a good relationship with friends and reading Qur'an (Quran) every morning. A study by Nashihin, which investigated differences in spiritual intelligence between students from non-Islamic high schools and those from Islamic-based high schools or Madrasah Aliyah in Jakarta, concluded that several dimensions of spiritual intelligence, such as life meaning, positive emotions, and rituals were higher among Madrasah Aliyah students than those among non-Islamic high school students. ${ }^{13}$

Based on the results of interviews with one of the Guidance and Counselling teachers of MAN 14 Jakarta, it was found that the average number of students who conducted weekly counselling was 25-30 students. The majority of these students were students of class XII. Also, most students' problems consulted in class XII were anxiety about determining a major in college and anxiety when approaching exams. No previous studies have been found that examine parenting styles, spirituality, and academic stress levels in Islamic-based schools. Therefore, this study is focused on investigating the relationship between these three variables in an Islamic-based school.

\section{Design and Methods}

This study used a descriptive-correlation research design with a cross-sectional approach. The research was approved by The Ethics Committee of Faculty of Nursing, Universitas Indonesia with number SK-157/UN.F12.D1.2.1/ETIK2020 on May $4^{\text {th }} 2020$. This research was conducted on students of MAN 14 Jakarta, located in the East Jakarta. A total of 109 students were included in this study. Students were recruited using a simple random sampling technique. Data collection was carried out online starting from April $3^{\text {rd }}$ to May $10^{\text {th }}, 2020$. Authors reviewed the collected data to ensure that the questionnaire was complete. Then, the data were encoded into numbers and imported into computer software.

This study examined the correlations of the variables. Data, including age, gender, tutoring, and parents' income, were collected. The age variable was used to determine the average age of students, while the gender variable determines the proportion of males and females. The academic tutoring variable was used to identify the number of respondents who took academic tutoring and did not take academic tutoring because it can affect academic stress. ${ }^{14}$ The parents' income variable was then used to determine the average income of students' parents because it can also affect student academic stressors. ${ }^{15}$ In this study, these variables also identified their relationship with academic stress.

Besides, this study used three instruments, namely, the Parental Care Style Questionnaire, ${ }^{16}$ the Spiritual Involvement and Beliefs Scale instrument, ${ }^{17}$ and the Educational Stress Scale for Adolescents. ${ }^{18}$ Before data collection, these instruments were tested on 30 students from MAN 14 Jakarta outside the study sample for validity and reliability. The validity and reliability tests were conducted using Pearson Product Moment (r) and Cronbach's Alpha. The Parental Care Style Questionnaire consists of 35 questions regarding parenting style, as follows: 11 democratic questions, 11 authoritative questions, and 13 permissive parenting questions with the results of $0.413-0.865$ for validity and 0.819 0.878 for reliability. The Spiritual Involvement and Beliefs Scale was used to measure the level of spirituality. The instrument consists of 26 questions with 17 positive meaningful questions and 9 negative meaningful questions. The validity test results showed a range of values from 0.406 to 0.852 , with the reliability of 0.945 . The Educational Stress Scale for Adolescents was used to measure the level of academic stress. The instrument consisted of 16 questions with the validity test results ranging from 0.424 to 0.754 and 0.845 for reliability. All three instruments were valid and reliable.

\section{Results}

The results from 109 participants showed that grade XII students' average age at the Islamic-based school, MAN 14 Jakarta was 17.54 years. The gender of the students in this study was dominated by 70 female students $(64.2 \%)$, while male students were 39 $(35.8 \%)$. Male students had the highest percentage of low $(2.56 \%)$ and moderate $(79.48 \%)$ academic stress. In contrast, female students had the highest percentage of high $(22.85 \%)$ academic stress.

Fifty students $(45.9 \%)$ attended academic tutoring, while 59 students $(54.1 \%)$ did not attend academic tutoring. Students with low academic stress $(1.69 \%)$ did not attend academic tutoring. Students who did academic tutoring had a higher percentage of high academic stress (24\%) than students who did not take academic tutoring (18.64\%). Most parents had an income range of 500,000 Indonesian rupiah (IDR) - 5,000,000 IDR. The parents' average income was 5,090,825.69 IDR. The lower the income of the parents, the higher the level of academic stress of the students. Students had a high level of academic stress with parents who earned 5,000,000 IDR and below. Meanwhile, no student had a high academic stress level with parents who had an income of 6,000,000 IDR and above.

The Pearson correlation test results for the variables of parenting style and academic stress level are shown in Table 1. The analysis results show that there was a significant relationship between the three types of parenting style and the level of academic stress. The relationship between democratic parenting style and academic stress level was the most significant compared to the other two parenting styles ( $\mathrm{p}=0.000 ; \alpha=0.05)$.

Based on Table 1, democratic parenting style and academic stress level had a significant negative relationship with a reasonably strong correlation $(\mathrm{r}=-0.451)$. The significant negative relationship indicates that the more the parents were perceived to be using the democratic parenting style, the lower the academic stress of adolescent students at the Islamic-based school.

Authoritative parenting style and academic stress level had a significant positive relationship with a weak correlation $(\mathrm{r}=0.201)$. A positive relationship means that the more the parents were per- 
ceived to be using the authoritative parenting style, the higher the students' academic stress would be. Moreover, the permissive parenting style and academic stress level had a significant positive relationship with a weak correlation $(r=-0.270)$.

Pearson correlation test was also used to analyse the relationship between spirituality and the level of academic stress. The results of the analysis can be seen in Table 2 . The Pearson correlation test results show that there was a significant relationship between the level of spirituality and the level of academic stress $(p=0.000 ; \alpha=0.05)$. The relationship between the two variables was negative, and the correlation was quite strong $(r=-0.430)$. This relationship implies that the higher the level of spirituality, the lower the level of academic stress of students in Islamic based schools.

\section{Discussion}

According to Curtis, the age range of 17 to 21 is considered late adolescence. ${ }^{19}$ Class XII students at MAN 14 Jakarta are categorised as late adolescence. Kinantie et al. highlight that there is an increasing complexity of thought processes in adolescence. ${ }^{20}$ It causes cortisol increases significantly. Cortisol, as a hormone that responds to stress increases when the stimulus and individual's perception of environmental threats also increase. ${ }^{21}$ Thus, adolescents are prone to stress, including academic stress, because they spend more time at school and academic tutoring classes.

Gender can affect the level of stress of an individual. ${ }^{1,22}$ A study carried out by Kountul et al. that involved 257 students in Manado, found a relationship between gender and stress. ${ }^{23}$ Male students experienced more mild stress $(22.9 \%)$ than severe stress $(21.1 \%)$. In contrast, female students experienced more severe stress $(35 \%)$ than mild stress $(30 \%)$. Men have been trained to become a leader and have independent, forceful, and confident personalities. Therefore, men can perceive academic failure and success as their endeavour. ${ }^{18}$ Women tend to use feelings when dealing with problems, while men use their logic and rationale in solving problems. However, each individual will differ in dealing with stress, regardless of gender. ${ }^{3}$

A study by Sun regarding academic stress in Chinese adolescents found a positive relationship between private tutoring and extra classes with an increase in some aspects of academic stress. ${ }^{14}$ One of the factors that influence academic stress is learning bur-

Table 1. Pearson correlation test for parenting style and academic stress level $(\mathbf{n}=109)$.

\begin{tabular}{lcc} 
Variable & \multicolumn{2}{c}{ Academic stress level } \\
& $\mathbf{r}$ & $\mathbf{p}$ \\
Democratic parenting style & -0.451 & 0.000 \\
Authoritative parenting style & 0.201 & 0.036 \\
\hline Permissive parenting style & -0.270 & 0.005 \\
\hline
\end{tabular}

Table 2. Pearson correlation test for spirituality level and academic stress level $(n=109)$.

\begin{tabular}{lcc} 
Variable & \multicolumn{2}{c}{ Academic stress level } \\
& r & P \\
Spirituality level & -0.430 & 0.000 \\
\hline
\end{tabular}

den. ${ }^{14}$ Private lessons and extra classes can increase study time. The increase in study time will also increase the learning burden, resulting in an increase in academic stress level. ${ }^{14}$ A study conducted in Hong Kong comparing the strengths and weaknesses of academic tutoring among students emphasised that tutoring can help students who have a delay in learning and develop student achievement. However, it may become a stressor, too. ${ }^{15}$ Thus, sometimes academic tutoring is not always practical.

According to Braya, low-income households cannot provide certain types of support for children as much as high-income households. Low-income households will also put pressure on the family. ${ }^{15}$ Low-income parents tend to have many burdening thoughts, such as paying school fees and fulfilling daily family needs. This condition makes parents busy. They focus on their work, so their attention to their children decreases. Externally, it is difficult for students to reduce academic stress because parental attention, such as free time to spend with their children, is limited since they are busy working. Besides, internally, children's academic stress level can also increase because they are thinking about their parents who have difficulty paying their school fees.

This study resonates with research carried out by Tujuwale et al. and Arsyam et al. Tujuwale et al. conducted a study that involved 91 respondents about the relationship between parenting styles and the level of depression in students of class X at SMAN 1 Amurang. ${ }^{24}$ They found a negative relationship between parenting styles and the level of depression. Moreover, Arsyam et al. investigated the relationship between parenting styles and the level of depression in 136 adolescent students at SMAN 1 Sinjai Timur. ${ }^{25}$ They underlined that students with the category of not experiencing depression came from parents who applied democratic parenting style. Adolescents tend to interact with people outside their family circle, such as peers and school friends. ${ }^{26}$ Therefore, parents' parenting style can influence crises that occur inside the family and outside the environment of adolescents. According to Hoskins, the ideal form of parenting style is democratic because it can reduce depression in children. ${ }^{10}$ Democratic parenting style can be a good source of support for adolescent students in Islamicbased schools to cope with students' academic burden. Parents who use democratic parenting style have wise, responsive, and warm attitudes. ${ }^{27} \mathrm{~A}$ warm attitude from parents can improve the harmonious relationship between parents and students of Islamicbased schools. This parenting style will make students of Islamicbased schools more active, so they do not hesitate to express their feelings and share their stories and school problems. The openness makes their parents more sensitive to their problems and finds solutions through discussion. Thus, parents can provide appropriate support to students of Islamic-based schools to reduce the level of academic stress. This study is recommended to provide training for parents about proper parenting style for late adolescents according to their developmental stages. This study suggests parents use the democratic parenting style by encouraging and giving comfort to their children to be open to parents about their academic problems. Schools are expected to maximise the role of Guidance and Counselling teachers in counselling, especially regarding academic stressors and provide potential solutions.

This study is related to research conducted by Safitri and Hidayati; they examined the relationship between parenting styles and depression levels of 130 adolescent students of class X at SMK 10 November Semarang. ${ }^{28}$ The results indicated a significant positive relationship between authoritative parenting style and the level of depression. Devani also researched on the relationship between authoritative parenting style and academic stress in high school students in Yogyakarta. ${ }^{29}$ The study involved 241 students of class X and XI aged 15-17 years. The results showed a positive 
relationship between authoritative parenting style and academic stress. Authoritative parenting style is defined as a type of parenting with strict rules and controls. ${ }^{10}$ Based on the analysis in this study, the fact that adolescent students in the Islamic-based school spent more time at school made parents tend to set strict controls hoping that a crisis would not occur in the family. Strict controls make adolescents more depressed and make them even further away. They also become more afraid, passive, and closed to their parents about themselves, including their academic stress. According to Sun et al., several factors lead to students' academic stress, including learning burden, grades, expectations, hopelessness, and assignments. ${ }^{6}$ When students are not open about their academic pressures, parents become unaware of their problems. Therefore, parents cannot give adequate support, resulting in an increase in academic stress in students of Islamic-based schools that may lead to depression.

The results of Garcia and Serra's research on parenting styles and emotional conditions of 2,069 respondents, of whom were 602 adolescents aged 12-17 years, are also in line with this study. Garcia and Serra found that permissive parenting style was associated with low emotional instability scores. ${ }^{27}$ Wardani investigated the relationship between parenting styles and stress in 124 adolescent students at SMPN 3 Gamping, Sleman, Yogyakarta, and reported a significant negative relationship between permissive parenting style and adolescent stress. ${ }^{30}$ Permissive parenting style refers to parenting with a warm attitude and not having strict controls. ${ }^{10}$ According to Morshidi and Hussein, permissive parenting occurs when parents give more sympathy and encouragement to their children without any demands. ${ }^{31}$ Parents who always spoil the students without any demands make them feel safe and comfortable because their needs are always fulfilled. Parents can be good listeners and support the students, including when they are experiencing stress because of academic burdens. On the other hand, parents also do not require students to study hard and excel at school. This type of support and attitude that parents have can reduce students' academic stress of Islamic-based schools.

The result of this study on an aspect of spirituality is related to research conducted by Krok. He examined the relationship between spirituality and stress management in 221 late adolescents at 16-20 years. ${ }^{12} \mathrm{He}$ concluded that spirituality is associated with the task-oriented coping approach to stressful situations. Therefore, students could generate alternative problem-solving. Munif et al. also carried out a study regarding the effect of Islamic Spiritual Mindfulness on stress in 36 nursing students aged 2123. ${ }^{32}$ The study found that Islamic Spiritual Mindfulness was proven effective in reducing academic stress levels. According to Berman et al., the development of spiritual maturity during adolescence is usually obtained from the family environment and external environment, such as schools. ${ }^{1}$ Adolescents spend more time at school, so they can be stressful. Spiritual beliefs in adolescents can guide and support them in dealing with problems, including academic stress. Islamic-based schools can provide an environment that supports the development of students' spirituality by nurturing Islamic values. Thus, students are closer to God and can establish good relationships with their peers and the environment.

Fisher suggests that the spiritual realm includes both communal and transcendental relations. ${ }^{33}$ In this Islamic-based school, good relationships with friends create a sense of mutual support among students that can ease the academic burden. This circumstance can reduce anxiety and motivate students. They do not feel alone in completing assignments and exams at school. A good relationship with God makes students believe that with every difficulty comes relief. Thus, students become calmer. Students also become more confident in completing their school tasks. The examination will not be perceived as a burden by students. Instead, they will study well and believe that they will get the result in return for the effort they make. Thus, the spirituality of adolescent students at the Islamic-based school MAN Jakarta Timur can reduce academic stress levels. This study suggests that nurses deliver health education programs to prevent academic stress in students and encourage adaptive coping and improve spirituality. Schools should carry out routine religious programs, such as reading the Qur'an every day in class before the Teaching and Learning Activities (KBM) take place and increasing joint activities to maintain harmony among school members.

Correspondence: Achir Yani S. Hamid, Department of Mental Health Nursing, Faculty of Nursing, Universitas Indonesia, Jalan Prof. Dr. Bahder Djohan, UI Depok Campus, West Java 16424, Indonesia. Tel .+62.21.78849120 - Fax: +62.21.7864124.

E-mail: achir@ui.ac.id

Key words: Academic stress; adolescent; Islamic school; parenting style; spirituality.

Contributions: INDU, concept and design, data collector, analysis and interpretation of data, drafting, and manuscript revision; AYSH, concept and design, analysis and interpretation of data, communication with the funder. All the authors have read and approved the final version of the manuscript and agreed to be accountable for all aspects of the work.

Conflict of interest: The authors declare that they have no competing interests, and all authors confirm accuracy.

Acknowledgments: The authors acknowledge Direktorat Riset \& Pengembangan, Universitas Indonesia, for granting the PUTI Prosiding 2020 with contract number NKB-3431/UN2.RST/ HKP.05.00/2020. The authors would also like to thank the Kanwil Kementerian Agama DKI Jakarta and MAN 14 Jakarta's Headmaster, who gave the authors' permission to collect the data. The authors also thank the students of class XII MAN 14 Jakarta who participated in this study.

Institution where the research was carried out: MAN 14 Jakarta.

Ethics approval and consent to participate: The research was approved by the Ethics Committee of Faculty of Nursing, Universitas Indonesia with number SK-157/UN.F12.D1.2.1/ETIK2020 on May $4^{\text {th }} 2020$.

Availability of data and materials: The data analysed are available from the corresponding author on reasonable request.

Conference presentation: This final manuscript has been presented at $7^{\text {th }}$ Virtual Biennial International Nursing Conference, Faculty of Nursing, Universitas Indonesia on September $24^{\text {th }}$, October $30^{\text {th }}$, November $16^{\text {th }} 2020$.

Received for publication: 30 July 2020.

Accepted for publication: 1 February 2021.

oCopyright: the Author(s), 2021

Licensee PAGEPress, Italy

Journal of Public Health Research 2021; 10(s1):2230

doi:10.4081/jphr.2021.2230

This work is licensed under a Creative Commons Attribution NonCommercial 4.0 License (CC BY-NC 4.0). 


\section{References}

1. Berman A, Snyder S, Frandsen G. Fundamentals of nursing: concepts, process, and practice. 10th ed. Hoboken: Pearson Education; 2016.

2. Sandal RK, Goel NK, Sharma MK, et al. Prevalence of depression, anxiety and stress among school going adolescent in Chandigarh. J Family Med Prim Care 2017;6:405-10

3. Videbeck S. Psychiatric-mental health nursing. Philadelphia: Lippincott Williams \& Wilkins; 2017.

4. Potter PA, Perry AG. Fundamentals of nursing. Maryland Heights: Mosby Elsevier; 2013.

5. Smeltzer SC, Bare BG, Hinkle JL, Cheever KH. Handbook for Brunner \& Suddarth's textbook of medical-surgical nursing. Philadelphia: Lippincott Williams \& Wilkins; 2010.

6. Sun J, Dunne MP, Hou X, Xu A. Educational stress scale for adolescents: development, validity, and reliability with Chinese student. J Psychoeduc Assess 2011;29:534-46.

7. Barseli M, Ifdil I, Nikmarijal N. Konsep stres akademik siswa [Concept of student academic stress].[Article in Indonesian]. Jurnal Konseling dan Pendidikan 2017;5:143-8.

8. Ministry of Health of the Republic of Indonesia. Hasil utama riskesdas 2018 [Main results of basic health research 2018].[In Indonesian]. Jakarta: Ministry of Health of the Republic of Indonesia. Available from: https://kesmas.kemkes.go. id/assets/upload/dir 519d41d8cd98f00/files/Hasil-riskesdas2018_1274.pdf

9. Putri KH. Hubungan pola asuh orang tua dengan tingkat stres remaja di SMKN 1 Padang [The relationship between parenting style and the stress level of adolescents at SMKN 1 Padang].[Unpublished thesis, in Indonesian]. Padang: Universitas Andalas; 2016.

10. Hoskins DH. Consequences of parenting on adolescent outcomes. Societies 2014;4:506-31.

11. Yusuf A, Nihayati H, Iswari M, Okviasanti F. Kebutuhan spiritual: konsep dan aplikasi dalam asuhan keperawatan [Spiritual needs: concepts and applications in nursing care]. [Book in Indonesian]. Jakarta: Mitra Wacana Media; 2017.

12. Krok D. Religiousness, spirituality, and coping with stress among late adolescents: a meaning-making perspective. J Adolescence 2015;45:196-203.

13. Nashihin MI. Perbedaan kecerdasan spiritual antara siswa sekolah menengah atas (SMA) dan siswa madrasah aliyah (MA) [Differences in spiritual intelligence between high school students and madrasah aliyah students]. [Unpublished thesis, in Indonesian]. Jakarta: Universitas Islam Negeri Syarif Hidayatullah; 2015.

14. Sun J. Educational stress among Chinese adolescents: measurement, risk factors and association with mental health. Unpublished thesis. Brisbane: Queensland University of Technology; 2012.

15. Bray M. Benefits and tensions of shadow education: comparative perspectives on the roles and impact of private supplementary tutoring in the lives of Hong Kong students. J Int Compar Educ 2013;2:18-30.

16. Yuriza WO. Hubungan jenis pola asuh orang tua dan tingkat stres dengan perilaku yang dipersepsikan mengakses situs porno pada remaja awal [The relationship between types of parenting style and stress level with perceived behavior of accessing porn sites among teenage girls]. [Unpublished thesis, in Indonesian]. Depok: Universitas Indonesia; 2018.

17. Hatch RL, Burg MA, Naberhaus DS, Hellmich LK. The spiritual involvement and beliefs scale: development and testing of a new instrument. J Fam Practice 1998;46:476-86.

18. Wulandari R. Gambaran tingkat stres akademik pada remaja di
SMA Negeri 1 Depok [An overview of the level of academic stress in adolescents at SMA Negeri 1 Depok]. [Unpublished thesis, in Indonesian]. Depok: Universitas Indonesia; 2014.

19. Curtis AC. Defining adolescence. J Adolesc Fam Health 2015;7:2.

20. Kinantie OA. Gambaran tingkat stres siswa SMAN 3 Bandung kelas XII menjelang ujian nasional 2012 [Description of the stress level of students of SMAN 3 Bandung class XII ahead of the 2012 national exam]. [Article in Indonesian]. Students e-Journals 2012;1:1-14.

21. Cameron CA, McKay S, Susman EJ, et al. Cortisol stress response variability in early adolescence: attachment, affect and sex. J Youth Adolescence 2017;46:104-20.

22. Sharma M, Kaur G. Gender differences in procrastination and academic stress among adolescents. Indian J Soc Sci Res 2011;8:1227.

23. Kountul YPD, Kolibu FK, Korompis GEC. Hubungan jenis kelamin dan pengaruh teman sebaya dengan tingkat stres mahasiswa fakultas kesehatan masyarakat Universitas Sam Ratulangi Manado [The relationship between gender and peer influence with stress levels of students in the faculty of public health at Sam Ratulangi University, Manado]. [Article in Indonesian]. Jurnal Kesmas 2018;7. Available from: https://ejournal. unsrat.ac.id/index.php/kesmas/article/viewFile/22558/22249

24. Tujuwale A, Rottie J, Wowiling F, Kairupan R. Hubungan pola asuh orang tua dengan tingkat depresi pada siswa kelas X di SMA Negeri 1 Amurang [The relationship between parenting style and depression level in class $X$ students at SMA Negeri 1 Amurang].[Article in Indonesian]. eJurnal Keperawatan 2016;4:18.

25. Arsyam S. Hubungan pola asuh orang tua dengan tingkat depresi pada remaja di SMA Neg. 1 Sinjai Timur [The relationship between parenting style and depression level in adolescents in SMA Neg. 1 East Sinjai]. [Unpublished thesis in Indonesian]. Makassar: Universitas Islam Negeri Alauddin; 2010.

26. Potts NL, Mandleco BL. Pediatric nursing: caring for children and their families. New York: Cengage Learning; 2012.

27. Garcia O, Serra E. Raising children with poor school performance: parenting styles and short- and long-term consequences for adolescent and adult development. Int $\mathrm{J}$ Environ Res Public Health 2019;16:1089.

28. Safitri Y, Hidayati E. Hubungan antara pola asuh orang tua dengan tingkat depresi remaja di SMK 10 November Semarang [The relationship between parenting style and the level of depression in adolescents at SMK 10 November Semarang]. [Article in Indonesian]. Jurnal Keperawatan Jiwa 2013;1:11-7.

29. Devani F. Hubungan antara pola asuh otoriter dengan stres akademik pada siswa SMA di Yogyakarta [The relationship between authoritarian parenting and academic stress in high school students in Yogyakarta]. [Unpublished thesis, in Indonesian]. Yogyakarta: Universitas Islam Indonesia; 2018.

30. Wardani GAK. Hubungan pola asuh orang tua dengan stres pada remaja di SMP Negeri 3 Gamping Sleman Yogyakarta [The relationship between parenting style and stress in adolescents in SMP Negeri 3 Gamping Sleman Yogyakar)]. [Unpublished thesis, in Indonesian]. Yogyakarta: Universitas 'Aisyiyah; 2017.

31. Morshidi M, Hussein MZSM. The effect of parenting style on adolescent's perception towards road safety. Int J Built Environ Sustain 2020;7:11-20.

32. Munif B, Poeranto S, Utami YW. Effects of islamic spiritual mindfulness on stress among nursing students. Nurse Media J Nursing 2019;9:69-77.

33. Fisher J. The four domains model: connecting spirituality, health, and well-being. Religions 2011;2:17-28. 